\title{
Development of the Algerian Sociolinguistic Landscape: Preliminary Observations
}

\author{
Belahcen Abbassia \\ Department of English, Faculty of Letters, Languages and Arts, University of Djillali Liabes, Sidi-Bel-Abbes, Algeria \\ Email address: \\ belahcenabbassia9@gmail.com

\section{To cite this article:} \\ Belahcen Abbassia. Development of the Algerian Sociolinguistic Landscape: Preliminary Observations. International Journal of Language \\ and Linguistics. Vol. 9, No. 3, 2021, pp. 80-91. doi: 10.11648/j.ij11.20210903.13
}

Received: April 20, 2021; Accepted: May 11, 2021; Published: May 21, 2021

\begin{abstract}
The prime goal of the present paper is to focus upon actual sociolinguistic profile in Algeria as both a diglossic and multilingual speech community. Thus, this social context has shown an extremely complex matrix of languages and dialects and their unstable functional roles in connection to situational language use. To cope with this scope we relied upon our observation in formal educational settings and other informal ones. Thus, our findings reveal a progress of the Algrian sociolinguistic profile owing to the multidimensional configuration of, first; language use which constitute of standard language systems that are Arabic, Tamazight, and French. In addition to, dialects or non- standard language varieties: Algerian Arabic and Algerian Berber. Second, by the unstable role of H/ L varieties and the widespread of monolingualism and the disappearance of loanwords in youth's language use as an indicator of language change in progress. Eventually, we can discern these preliminary findings to raise our awareness not only about the authentic status of languages, but about the future of languages and dialects in Algeria.
\end{abstract}

Keywords: Language Contact, Bilingualism, Diglossia, Standard Languages

\section{Introduction}

Just like the other countries of the Maghreb, two highstatus languages play a central role in society Standard Arabic and French, and their presence is visible in people's language use, though to varying degrees. Because of the illiteracy factor, diglossia shows to be unstable i.e. the dysfunctional role of $\mathrm{H} / \mathrm{L}$ language varieties.

Furthermore, youth's language behaviour in the actual globalised world showed a myriad and contradictory behaviour. Our observation to this group of young speakers in both formal and informal settings raised our awareness about a phenomenon which emerged recently. To be monolingual is something normal, to be a multi-/ or bilingual is normal, too. But, what is puzzling is that our young generation who have certainly possess an already acquired/ or learnt a linguistic repertoire of several language varieties in their speech community to be used appropriately according to the addressee, the type of setting, the topic...etc., are becoming monolinguals and have a tendency to use only the mother tongue. The latter which is so distinct from their elders' dialect in many respects; it is restricted or no use of loanwords, and their speech is characterized by a countless linguistic innovations.

This may be explained as the effect of arabization process and ideology among other factors, and no consensus could be achieved that Standard Arabic can be used or replace the mother tongue by any portion of the community.

Thus, the Algerian linguistic situation has witnessed untold changes and multitudinous development. So, what are the factors responsible for bringing these changes at the microsociolinguistic level and importantly at the macrosociolinguistic level? In other terms, how can sociolinguists and language planners scrutinize as adequately as possible in a convenient way the sandardisation of Tamazight, the unstable functional roles of $\mathrm{H} / \mathrm{L}$ language varieties, and the process of language change either in progress or completed as driven by youths. To put it in a nutshell, is Ferguson"s formula [18] still be appropriate to describe the Algerian linguistic prolfile?

Attempting to answer our concern, the present paper is constructed of a variety of sections which deal with a description of languages and dialects used, in addition to a study of language contact and namely its effects and 
outcomes. Diglossia as a linguistic phenomenon; which characterizes not only Algeria, but touches the whole Arab countries was reviewed. These parts are meant to well describe and present the possible explanations which may exhibit the authentic interplay of the dialects and languages in use. To issue what was stated to be elucidation of our earlier concern which would eventually draw a clear image about how the actual sociolinguistic matrix is constructed and under what factors do languages and dialects interact to fit usefully and appropriately a given situational language use in connection to its level of formality.

\section{Overview of the Language Varieties in Presence: Roles and Relationships}

Algeria defines itself as part of the Arab and Muslim world. The majority of the population is Arabo-phone and speaks a vernacular variety of Arabic. In addition, a minority of Berber phones speak Berber dialect, in addition to, its related standard variety which is Tamazight. The French language has also a prominent status in society, which it has retained since the colonial period.

Standard Arabic or fuşћa was the only formal language that is officially recognized. It is used in news, in TV programs, in religious and literary purposes, and of course in education. However, the situation has changed and Tamazight gained a national, then, an official status. Besides, the linguistic situation in the Algerian context is quite similar to the other Maghreb countries as it is characterized by a double phenomenon, diglossia and bilingualism. The former phenomenon indicates the presence of two language varieties, one standard and the other dialectal. The latter phenomenon, i.e. bilingualism, refers to the presence of two genetically unrelated languages, Arabic and French that are attested in the Algerian speech community as a whole ${ }^{1}$.

Linguists (Grandguillaume [22], Bouamrane [9], TalebIbrahimi [37] and Bouhadiba [10] view this linguistic situation as a much more complex situation. Bouhadiba [10], on the one hand, discusses this situation by adapting Ferguson's formula [18]; this latter was given as follows:

$$
\begin{aligned}
\text { Algeria } 3 \mathrm{~L} \longrightarrow & \text { 2LmajL. } 1(\mathrm{CA}, \mathrm{SA}, \mathrm{LA}, \mathrm{MSA}, \mathrm{ESA}, \mathrm{LW}, \\
& \mathrm{V})^{2}+1(\mathrm{~S})(\mathrm{V})+1 \mathrm{Lmin}\left(\mathrm{V}_{2}\right)
\end{aligned}
$$

In this formula, three languages are mentioned; two of them are major $^{3}$ languages (2Lmaj): Standard Arabic (SA)

\footnotetext{
${ }^{1}$ The term diglossia is used here in Fishman's [19] definition of the term, i.e., to cover functionally differentiated language varieties of whatever kind.

Following Wexler [40], we distinguish between intra-lingual diglossia where the language varieties are genetically related and inter-lingual diglossia where they are not. Bilingualism is used here to mean the use of two or more languages in contrastive distribution

${ }^{2}$ The following acronyms cited in the formula above stand for: CA: Classical Arabic, SA: Standard Arabic, LA: Literary Arabic, MSA: Modern Standard Arabic, ESA: Educated Spoken Arabic, LW: Lugha 1 wusta, V: Dialects (vernaculars).

${ }^{3}$ For more details the notions of major and minor languages was clearly explained by [10] Bouhadiba. 1998, p. 11.
}

which exists along with several dialectal forms (V) or minor language varieties and the other major language is French, and the low varieties: Algerian Arabic and Berber ${ }^{4}$ dialects.

On the other hand, Taleb Ibrahimi [37] suggests another model. She is convinced that the existence of only Classical Arabic, Algerian Arabic, and French does not really reflect the Algerian linguistic situation. That is why she has proposed a model on which her analysis is based. Her model takes for granted the dynamic nature of both society and language. She [37] says that:

...Between the Arabic of the Koran and spoken Arabic known as dialectal, Arabic establishes a scale of five levels, consisting of:

1) Classical Arabic

2) Standard Arabic (or modern)

3) Sub-Standard Arabic, represented by the spoken form, a standard used among educated people

4) The spoken Arabic used by school children who raise the level of the dialect.

5) The dialects which are specific to regional entities and susceptible to evolve in the framework of unification around the spoken forms of big towns (koineization). ${ }^{5}$

Therefore, the Algerian landscape is characterized by a multiplicity of languages and language varieties used for different specific daily uses, as presented in the following sections.

\subsection{Arabic}

Officially speaking, in Article 5 of the 1963 Algerian Constitution, Standard Arabic is officially the only language allowed in administration, teaching and the media: la langue arabe est la langue nationale et officielle de l'Etat. Tamazight is however, recognized and is present in the preamble of the constitution of 1996 (modifying Article 3 of the February 1989 constitution), as a fundamental component of Algerian identity, with Islam and Arabity (ibid.).

Linguistically speaking, according to researchers, notably Sayahi [34], Arabic, in its different varieties, is one of the five most spoken languages in the world today. He [34] adds:

$C A$ has a rich consonant system with, on the other hand, a reduced vowel inventory. There is a total of twenty-eight consonants (including four emphatic consonants), some of which are not present or are of a reduced use in the majority of the national vernaculars, such as the glottal stop and, to a

${ }^{4}$ Berber is a spoken dialect; it became a national language in 2002 and an official language in 2016.

${ }^{5}$ Quoted in [37] Taleb Ibrahimi. 1997, p. 9. My translation; the original passage reads as follows:

Entre l'arabe du Coran et l'arabe parlé dit dialectal, l'arabe établit une échelle à cinq paliers, comprenant:

a. l'arabe classique, l'arabe standard (ou moderne)

b. l'arabe sub-standard, représenté par l'oral, standard utilisé entre les gens cultivés.

c. L'arabe parlé par des scolarisés qui relèvent leur niveau de dialecte.

d. Les dialectes propres à des entités régionales, susceptibles d'évoluer dans le cadre d'une unification autour des parlers des grandes villes (koinésation)

${ }^{6}[34]$ Sayahi. 2014, p. 24 
lesser extent, the interdental fricatives. As for the vowels, $C A$ has three short vowels (/a/, /i/, /u/) that are not separate letters but added as diacritic marks to the preceding consonant. These same vowels can be elongated and become long vowels or glides that are represented orthographically. At the phonological level, MSA in its written form preserves all the sounds present in Classical Arabic.

Besides, according to the formula mentioned above, the Arabic language consists of the two extremes of the pendulum; one is Classical Arabic and the other is Algerian Arabic. On the one hand, Classical Arabic is seen by Ferguson [16] as the prestigious language and serves formal purposes ${ }^{7}$. Benrabah [5] refers to an existing differentiation between, on the one hand, Baldi Arabic, referring to preHilalian urban varieties, a term that is also used in Tunisia, and, on the other, Barani, (literally outsider), in reference to rural dialects.

In spite of the superior or superposed status that the Arabic language has, it lacks the natural use in spontaneous conversations. All Arabs claim that they speak Arabic; nevertheless, it is no one's daily language behavior ${ }^{8}$. Kaye $[24]^{9}$ shares the same view, Classical Arabic is a somewhat artificial medium which has not had any native speakers, for at least ten centuries. However, a common feeling that all Arabs have toward the Arabic language is explained in relation to their psychological reality. They all value Arabic (i.e., fuşha), because in their view it is associated with Islam and the sacred book, the Kuran. Moreover, it preserves its prestige and its quality by its eloquence, high degree of rhetoric and beauty. In this respect, Benrabah [5] ${ }^{10}$ says:

The Arabic language and Islam are inseparable. Arabic has a privileged position as it is the language of the Koran and the Prophet, and the shared language of all Muslims in the world, language of science, language of culture.

Said (1967) [10], claims that Modern Standard Arabic is that variety of Arabic that is found in contemporary books, newspapers, magazines, and that is used orally in formal speeches, public lectures, and television.

This simplified version of Arabic is standardized and codified within the norms that enable Arabic speakers to understand each other and foreign individuals to learn it easily and more rapidly. Nevertheless, the modernity of the Standard Arabic consists of the autonomy, dynamicity, and development of it, as it is always hosting new terminology, loan words which are adapted to it and promotes a vivid and ever-updated language in need.

Unfortunately, not all Algerians do master Modern Standard Arabic, a baccalaureate or any graded individual is not able to read a newspapers' page without interpretation or pronunciation mistake, though Modern Standard Arabic is a national and official language in Algeria, policy makers seem

\footnotetext{
${ }^{7}$ To avoid any terminological problem between the two terms Classical Arabic, and Modern Standard Arabic; the term Standard Arabic is used in the present study to refer to the High variety.

${ }^{8}$ A notion dealt with by Parkinson [33].

9 [24] Kaye. 1994, p. 51-9.

${ }^{10}$ [5] Benrabah. 2007, p. 67.
}

to fail in upgrading Algerians to speak correct and mistakefree Standard variety of Arabic.

\subsection{Tamazight}

The term Tamazight is sometimes used to refer to an ethnic rather than to a linguistic ...language family though Chaker [34] suggests that both Berber and Tamazight are used interchangeably; according to him, the principal Berberspeaking region in Algeria, Kabyle, includes the two thirds of the Berber-speaking Algerians.

However, Berber is today becoming a national language and it is taught in (primary, intermediate, and secondary) schools and became an official language in 2016 and called Tamazight- sociolinguistically speaking it is the High variety and its Low variety is Berber used in all other daily situational circumstances.

In 2016, the Algerian parliament tackled questions concerning the language policy and planning organization. And the action toward the standardization of Tamazight is realised. Berber resistance to upgrade their language and culture has succeeded.

So, Imazighen is one language and one constituent of the linguistic landscape of Algeria. This profile has been drawn by many people of high and powerful positions who decide about the legal status of languages and their uses.

\subsection{French}

The strategic geographical situation that Algeria occupies within the Maghreb and its historical dynamics have paved the way to much more contact with other countries, like France, Spain and Italy. Being a colony, the presence of these peoples has led to the use of their respective language varieties, though to different extents. Indeed, the presence of several languages in Algeria was brought into existence by their native-speakers.

First, the presence of the Turks in Algeria and the influence of the Turkish language on the variety spoken by Algerians are attested by a worth noticing amount of borrowings, which still exist in speech. The presence of a big proportion of Spanish colonists and refugees of the Spanish Civil War showed its huge impact by the borrowings that are left in the speech of some dialects in the West of Algeria, particularly Oran. In addition, Italians came to East Algeria who were brought for the same purposes. Italian left its linguistic traces by means of linguistic borrowing into the Algerian variety, too.

However, the French occupation that lasted more than 130 years had the strongest influence on the Algerian society. In fact, French has acquired a significant status in Algeria and in nearly all the Maghreb countries, in which it became part of the linguistic system used by Algerians through the integration of French linguistic forms in both Algerian Arabic and Berber varieties. In the colonial period French was imposed on Algerians as the official language like the other Maghreb countries, a reason that paved the way to the use of French and has its actual status, due to the politics of the 
French colony which lies in the limited access of education to the natives.

The use of French language had a prominent position in society, though; it is used at different degrees by the majority. French is considered by the Constitution as a foreign language Morsly [29], [30]. President H. Boumediene defined the French language as: A foreign language which benefits from a special situation because of objective historical considerations Morsly [29] ${ }^{11}$. French is also considered as the language of chi-chi Morsly [32 $]^{12}$.

The other reason, on the other hand, is that the knowledge of French by Algerian citizens has emerged in the postcolonial period by the extension of the teaching system (all Algerian children must start their learning at the age of six), using French as the language of instruction rather than Arabic. As it was declared by Ben Bella, an important proportion of Algerians acquired certain competence in French, he said we think as Arabs, but we speak French Benrabah [5]. Owing to its linguistic system, Arabic was seen, as a classical, archaic language and that it did not suit the actual modernized society's needs of expression. In contrast, foreign languages are usually seen as an open window on modernity and development through a transfer of technology and scientific achievement. Algeria has a long history with the French language.

Eventually, Fr. is present in the Algerian linguistic landscape. It has had a privileged status in a variety of domains such as administration, teaching at the university, especially in the scientific subjects (e.g. medecines and technology), and in the economic and financial sectors. This is a paradoxical fact to the main objective of the Arabisation policy, which is to reduce rather than to extend the use of the French language. Today, French has entered into competition with the English language. This new status of English has been brought forward by the media, the Internet, and Satellite TV channels and very recently by the new Algerian relationships with the United States and Great Britain.

To escape Arabisation many parents (especially the elite) enrolled their children in private French schools Kateb [2] to ensure a bilingual education for them, but in 2006, president Abdel Aziz Bouteflika has ordered 42 private Frenchlanguage schools to be closed for linguistic deviation. Ait Larbi [2]. The rapid implication of Arabisation, in fact, caused a state of semi-bilingualism to most Algerians Moatassime [28], meaning that they possess a passive knowledge of both: Modern Standard Arabic and French. Despite the established language policy, French continues to be regarded as necessary for social and professional success, although further research is needed to confirm this.

\subsection{Mother Tongue (s)}

The present section will provide a clear-cut distinction between language varieties of the type dialects which are genetically unrelated and constitute the Algerian linguistic

\footnotetext{
${ }^{11}$ [29] Morsly. 1984, p. 25.

12 [32] Morsly. 1997, p. 16.
}

landscape. These dialects are Algerian Arabic which exhibit variation along the Algerian corners in addition to Berber- the spoken mode of kabylian population who are distributed around the center of Algeria, East and the South.

\subsubsection{Algerian Arabic}

The social and cultural backgrounds of Algerian Arabic dialect were exhaustively developed in another paper $^{13}$. In the present paper, we restrict our task to its sociolinguistic definition. We can define this dialectal variety, as the functional daily mode of expression. It is the vernacular used by the majority of Algerians, with slight marked discrepancies that affect its homogeneity. Nevertheless, along most Algerian cities different varieties remain mutually intelligible.

It witnesses a variety of linguistic processes due to the impact of the dynamics of language contact. Algerian Arabic is becoming a melting pot of different language varieties. It is a derived form from Standard Arabic, from which it structured its simplified intra-lingual system.

Algerian Arabic is also a mixed code, marked by the presence of a considerable amount of borrowed words, which have rooted into it from, first the Berber substratum, then, from Spanish, Turkish, and mainly French. The substratum effects of all these languages make this dialectal vernacular a mixed inter-lingual variety. Linguistic elements derived from all these distinct linguistic systems intermingled and interpenetrated in such a kind of co-existing linguistic system to make-up a complex system called: Algerian Arabic.

\subsubsection{Berber}

Berber existed in North Africa before the Arab conquest in the $7^{\text {th }}$ and $11^{\text {th }}$ centuries. In fact, the Arabisation that rooted in the Maghreb was not total; some important zones have remained Berber speaking up to the present time. The history of this language is to some extent ignored, a matter that is mentioned by Basset [4]: Berber is almost exclusively a spoken language, and its history, even in the recent period, is almost unknown owing to the lack of written documents.

The word Berber is originated from barbarian in official documents, which the Roman used to refer to people who refused to join their empire and which the Greek used before them also. The word Berber was later taken up by the Arab, although Middle Age writings in Arabic often used the termmazigh. Amazigh is how the Berbers call themselves.

Thus, because of the Arabisation in the early period of the Arab occupation Berber underwent regression in North Africa and was considered as a minor language. Berber speaking individuals are seeking a real status for this variety, especially in Algeria. Claims report that Berber has been suffering from regression not only in Algeria but in Morocco and Tunisia, too. Its status as a language stands on an unequal

13 As an informant responded to the questionnaire of [12] Caubet, it was a interesting opportunity to me to develop my awareness about dialectology and the linguistic analysis, particularly; the morphophonological study of Algerian Arabic dialect in a paper entitled: Belahcen, A. (2021a.) The Substratum Effect of Language Contact into Algerian Arabic Pattern Construction. In: Journal of Talīmija. 
footing with Arabic.

\subsection{Foreign Languages}

Besides to some foreign languages which are learnt such as Spanish, Italian, Russian, German; etc. they are restricted in use compared to the English language which recently, and in line of globalization and the development of sciences, technologies, and communication. Algeria is experiencing a new era of linguistic update, especially among recent generations and workers in direct exposure to English language in their occupations; English now has a promising status of competion with French language (Grandguillaume [21]. The new method English nations adapted for spreading English language was more effective than any other, by urging the need for learning it in order to gain interesting occupations, using different home appliance, computers, and such developed devices, due to the use of English in different domains without any negative attitude or misunderstanding which permitted the increase of English learning programs for foreigners.

\section{Language Contact: Situation and Outcomes}

Language contact inevitably leads to bilingualism. Generally, two types of bilingualism are distinguished: societal and individual bilingualism. The former occurs when in a given society two or more languages are spoken. In this sense, nearly all societies are bilingual, but they can differ with regard to the degree or form of bilingualism. (Appel et al. $[3]^{14}$.

From a theoretical linguistic perspective, we may distinguish the following:

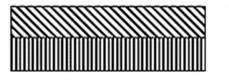

(I)

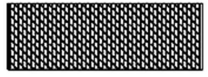

(II)

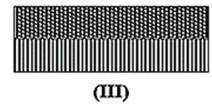

Key :

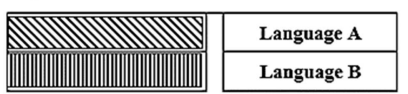

Figure 1. Schematically Represented Forms of Societal Bilingualism (Appel et al [3].

The above scheme represents three distinct social situations: I, II, and III; in which two different languages are present. In situation (I); the two languages are spoken by two distinct groups who are naturally supposed to be monolingual. It's a situation which lacks intergroup communication. This type of societal bilingualism may occur in former colonial countries, where the colonizer spoke $(\mathrm{X})$ language, and the native people a local language $(\mathrm{Y})$.

Besides, in situation (II); all people are considered to be bilinguals. Such a form of societal bilingualism requires that people have command of more than two languages, it is

\footnotetext{
${ }^{14}$ [3] Appel et al. 2005, p. 1-2.
}

found in societies such as India, Africa.

Then, in situation (III), we may distinguish two main groups: one is bilingual and the other remains monolingual. The latter group forms a minority, not quantitatively measuring the number of its population, but looking to it from a sociological term- it is a non- dominant or oppressed group.

Thus, whether or not the three situations do exist in a pure form in the actual world is a far-reaching answer to the issue. Statistically speaking, we cannot measure authentically the number of bilinguals and monolinguals and to a clear- cut precising the social matrix that embodies their groupings. What about the degree of language mastery of the languages themselves. It is fairly clear what individual bilingualism is, but determining whether a given person is bilingual or not is far from simple! Such an issue led many scholars (Appel et al [3] to raise many interrelated questions, which are complex and seem to be rather assumptions as such:

1) To what extent must a speaker have command over the two languages in order to be labeled a bilingual?

2) Must s/he have fluent oral and writing skills in both languages?

3) Must a true bilingual be proficient in productive (speaking, writing) as well as receptive (listening, reading)?

4) Which components of the language are the criteria: pronunciation, vocabulary, syntax, or pragmatics?

From an empirical linguistic perspective, the history of the study of bilingualism has known various definitions which were proposed, notably; by firstly, Bloomfield [8] ${ }^{15}$ who says that [a bilingual should possess a] ...native-like control of two or more languages. Secondly, and on the other extreme side, Macnamara [25] proposed that somebody should be called bilingual if he has some second language skills in one of the four skills or modalities (listening, speaking, reading, and writing), besides to his first language skills.

Furthermore, scholars point out to a problem of the psychological definition of, particularly, the individual bilingual. That is, in terms of proficiency; the problem emerged by the measurement task which is complex in itself. It is rather impossible to find a norm or any general standard way to measure the bilinguals' potentials and say, eventually, whether they are so proficient or not, for instance.

Nevertheless, to find an efficient way to deal with bilinguals, linguists proposed to deal with the issue from a sociological aspect. Weinreich [39] ${ }^{16}$, for instance, pioneered such type of investigation who said that: the practice of alternatively using two languages will be called here bilingualism, and the persons involved bilinguals. Within this definition, we may stress the fact that any person who regularly uses two or more languages in alternation, s/he is a bilingual. Again, within the same definition we should be careful about the fact that not all bilinguals are equal in their production, in other words, we cannot compare between bilinguals, but we can compare bilinguals with monolinguals

\footnotetext{
${ }^{15}$ [8] Bloomfield. 1933, p. 56.

${ }^{16}$ [39] Weinreich. 1953, p. 5.
} 
on the basis of their linguistic competence, according to different circumstances of language use. After all, we cannot impose standards to bilinguals.

\section{Diglossia: An Expository Account}

The concept of diglossia has been of vital interest to sociolinguists. The term characterizes a number of linguistic situations that have already deserved much attention in the socio-linguistic literature. According to Hudson [23], this term was eminently introduced in socio-linguistics by Ferguson [17] to describe a situation found in many different places like the Arab countries, Greece, German-speaking Switzerland and the Island of Haiti. Therefore, it is important to illustrate the subject matter mainly by giving Marçais's [26] definition, that of Ferguson [17], and that of Fishman [19].

First, Marçais [26] gave a definition of Arabic diglossia in his work entitled La Diglossie Arabe; relying on his observations of the linguistic situation in North Africa. He says

The Arabic language appears...under two perceptibly different aspects:(1) a literary language so-called written Arabic...or regular, or literal, or classical, the only one that has always and everywhere been written in the past, the only one in which still today are written literary or scientific works, newspapers articles, judiciary acts, private letters, in a word everything that is written, but which exactly as it is, has perhaps never been spoken anywhere, and which in any case is not spoken now anywhere,(2) spoken idioms, patois ... none of which has ever been written..., but which everywhere and perhaps for a long time are the only language of conversation in all popular and cultured circles. Marçais $[26]^{17}$.

According to Marçais's [26] definition, two points can be stated. One is the existence of two related but different forms of the same language. Second, each variety fulfils special functions; i.e. writing vs. speech.

Second, Ferguson $[17]^{18}$ defines diglossia as:

... a relatively stable language situation in which, in addition to the primary dialects of the language (which may include a standard or regional standards), there is a very divergent, highly codified (often grammatically more complex) superposed variety, the vehicle of a large and respected body of written literature, either of an earlier period or in another speech community, which is largely learned by formal education and is used for most written and formal speech purposes but is not used by any sector of the community for ordinary conversation.

Ferguson's definition, thus, explains a variety of facts of diglossia. Among these, he puts an emphasis on the fact that in diglossic situations, the High $(\mathrm{H})$ variety lives side by side with a Low (L) variety where the former is the superposed variety and the latter is the dialectal variety. Furthermore, he states that diglossia generally occurs in situations where: (1) the literacy rate is low and (2) there is a large body of

\footnotetext{
${ }^{17}$ [26] Marçais. 1930, p. 401.

18 [17] Ferguson. 1959, p. 310.
}

literature to which the community is very attached because it is culturally defining and has been around for a number of centuries. Ferguson [23] ${ }^{19}$, adds that no one is ever comfortable in $H$ to the extent that they are in $L$. That is, $\mathrm{L}$ variety is the language of everybody in the speech community, while the $\mathrm{H}$ is restricted to elites or to those who have an instruction, to be used formally.

However, other studies do not use the term in the sense that was designed by Ferguson, but to cover societies where several languages exist. Fishman $[19]^{20}$ uses the term to cover not only multilingual societies which officially recognize several languages and not only societies that use vernacular and classical varieties, but also societies which employ separate dialects, registers, or functionally differentiated language varieties of whatever kind. Therefore, Fishman uses the term diglossia to cover not only societies with only two language varieties which are genetically related but also situations where different languages are used. Fishman $[23]^{21}$ refers to Paraguay as an example of diglossic community, although the High and Low varieties are respectively Spanish and Guarani, an Indian language totally unrelated to Spanish.

Fishman [19] $]^{22}$ sees the term diglossia as a characterization of the social allocation of functions to different languages or varieties, meaning that a given speech community is said to be a diglossic one, unless the individual speakers will have a consent about which variety is either $\mathrm{H}$ or L. Similarly, Schiffman $[35]^{23}$ notes that in some linguistic cultures, all speakers exhibit diglossic behavior (i.e., use both $H$ and $L$ varieties in complementary distribution, while in others, only some members of the society do), [and] in many diglossic situations, only a minority or elite control the $H$ domain successfully.

Despite the distinct roles that each variety has, i.e. $\mathrm{H} / \mathrm{L}$, as in the Arabic speaking countries, there is still an ambiguous situation in which no distinction can be made between what variety is appropriate rather than the other in a given situation. This complex situation is due mainly to the presence of an intermediate variety. This latter is viewed by Bishai [7] as an Inter-Arabic language. Other scholars such as Badawi (1973) [9] refer to it as the Colloquial Arabic of the Intellectuals, while other linguists think that this variety is a simplified version of Standard Arabic ${ }^{24}$.

In addition, this simplified form, which is the outcome of the evolutionary character of Standard Arabic, does not correspond totally to the language of the Holy Koran. Standard Arabic has witnessed several changes at different linguistic levels what is known as Modern Standard Arabic. This linguistic evolution was the reason that led to the

\footnotetext{
${ }^{19}$ [23] Ferguson. 1959, p. 331 in: Hudson. 1996, p. 4.

${ }^{20}$ [19] Fishman. 1972, p. 92.

21 [23] Fishman. 1971 in: Hudson. 1996, p. 50.

22 [19] Fishman. 1972, p. 102.

23 [35] Schiffman. 1997, p. 212

${ }^{24}$ This form of Arabic is referred to as Modern Standard Arabic. This variety of Arabic is by no means a simplified version of Standard Arabic. Its grammar is the same as that of Standard Arabic.
} 
appearance of a variety of labels to Standard Arabic. One can

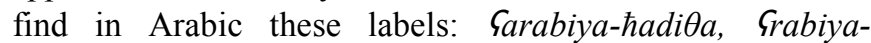
mu Saşira, Arabe Moderne Standard; in French, and Modern Standard Arabic; in English. This latter is defined by McLaughlin [27] ${ }^{25}$ as:

That variety of Arabic that is found in contemporary books, newspapers, and magazines, and that is used orally in formal speeches, public lectures, learned debates, religious ceremonials and in news broadcasts over radio and television.

According to Morsly [31], a further evolution of the relationship between the $\mathrm{H}$ variety and the $\mathrm{L}$ variety is marked by the appearance of what Ferguson calls al-Lughaal wuşta. ${ }^{26}$ Abdulaziz $[1]^{27}$ uses the term Modern Standard Arabic to designate this Arabic variety that is the result of the evolution of the Standard Arabic of the Holy Koran. He shows that this evolution is a necessity and is caused by the presence of new needs of expression; he says that it is $a$ vehicle of modern expression in all spheres of human endeavour.

So, the linguistic situation in the Arab speaking nations has known the emergence of Modern Standard Arabic. Consequently, this has led to the emergence of the concept of triglossia/or polyglossia; where exactly CA and dialectal Arabic constitute the extreme sides of the pendulum and an intermediate form of Arabic which is Modern Standard Arabic is the form used in teaching, news and other TV programs.

Abdulaziz [1] $]^{28}$ claims that: possibilities of a situation of triglossia also existed involving switching between all the three varieties. In this respect, Taleb Ibrahimi [37] says:

We can therefore propose a diagram which no longer represents diglossia but triglossia in which SA would occupy the third pole of the triangular model, while the arrows would indicate the mutual interactions between them ${ }^{29}$.

The following diagram illustrates clearly, what has been stated above:

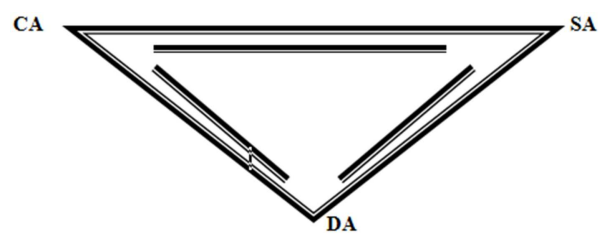

Figure 2. Triglossia Model (Taleb Ibrahimi $[37]^{30}$ ).

Nevertheless, Abdulaziz $[1]^{31}$ puts the emphasis on the

\footnotetext{
${ }^{25}$ [27] McLaughlin. 1972, p. 58.

${ }^{26}$ See Dendane $[14,15]$ for an exhaustive discussion about the development and discrepancies existing between the Classical Arabic and Modern Standard Arabic compared to Tlemcen variety as a case study.

${ }^{27}$ [1] Abdulaziz. 1986, p. 11.

28 [1] Abdulaziz. 1986, p. 22.

${ }^{29}$ The original passage reads as follow s (my own translation):

Nous pouvons donc proposer le schéma qui ne figurerait plus une diglossie mais une triglossie ou l'AS viendrait prendre le troisième pole du schéma triangulaire tandis que les flèches indiqueraient les interactions réciproques entre elles.

${ }^{30}$ [37] Taleb Ibrahimi. 1997, p. 32.

${ }^{31}$ [1] Abdulaziz. 1986, p. 23.
}

difficulty to discriminate the appropriate situation for appropriate language use. In fact, the relationship between these varieties, that he suggests to be vague, leads him to focus on the complexity of the situation saying that [The] discussion of [triglossia] is meant to stress the complexity of language use where the functions of the varieties interacting have not been quite stabilized.

In contrast, Youssi [41] ${ }^{32}$ identifies this intermediate variety. He assumes that the linguistic situation in Morocco, and in the whole Arab world, has been characterized by the existence of three varieties: literal or classical Arabic, Moroccan Arabic (or dialectal), and the intermediate variety. Thus, according to Youssi (ibid) Arab speaking countries are encountering a new and different situation from a diglossic to a triglossic /or polyglossic one. He says:

Sociolinguistically speaking, triglossia is a trilateral functional specialization... [in which] the intermediate variety has a function to reduce the conceptual and structural distance between both the native spontaneous Arabic of the daily life which is uniquely spoken, and the CA of intellectualization...[which is] uniquely written and premeditated.

Therefore, Youssi obviously mentions that a triglossic situation is meant to reduce the conceptual and structural distance between Standard Arabic and Dialectal Arabic. This provides an intermediate form of Arabic to simplify the Standard Arabic linguistic system to be used essentially by the elite in formal or official conversations.

Klauss (1966)[24] $]^{33}$ discussed the notion of genetically related or unrelated languages and put into these two propositions:

1. In-diglossia two varieties are closely related.

2. Out-diglossia, two varieties are unrelated.

Also Trudgill $[38]^{34}$ defines it as

a particular kind of language standardization, where two distinct varieties of language exist side by side throughout the speech community..... and where each of two varieties is assigned a definite function. So this means the characteristics and functions of high and low varieties.

However, there is still an ambiguous picture, on the one hand, because of the instability of the distinct linguistic situations. Morsly [31] says in this respect it is therefore difficult, in the absence of investigations and reliable descriptions, to determine the situation of the Arabic language in Algeria. ${ }^{35}$. On the other hand, this instability due to another phenomenon that characterizes the Algerian linguistic picture: the pervasive use of French, on the society following its long-term existence in the country. Therefore, the accurate analysis of the linguistic situation and the appropriate language use in distinct settings is difficult owing to the dynamic nature of language and society in a bilingual context.

\footnotetext{
32 [41] Youssi. 1983, p. 79.

33 [24] Klauss. 1966 in: Kaye. 1994, p. 138.

34 [38] Trudgill. 1974, p. 177.

${ }^{35}$ The original passage reads as follow:

Il est donc difficile, en l'absence d'enquêtes et de descriptions fiables de définir la situation de la langue Arabe en Algérie. (my translation)
} 
The actual situation reflects a rather conflicting view about particularly diglossia. There is a disruptive functional role of $\mathrm{H} / \mathrm{L}$ varieties in the Algerian context; this is due mainly to no mastery of $\mathrm{H}$ and standard languages by young generation, to be used formally, and, because of the high rate of illiteracy among old generation. In addition, the main outcome of languages in contact is merely bilingualism, the mixture of the linguistic components from distinct linguistic codes (SA, Tmzt, and Fr) within only one sentence. What characterizes the Algerian production is the code switching and borrowing, and the emergence of the Algérianisation of an important body of linguistic constituents to form, eventually, a peculiar system called Algerian Arabic distinct, for instance, from the contiguous countries dialectal forms. Besides, this process of Algérianisation is of a paramount importance, especially, at the morphophonological level of this vernacular.

Thus, it is already stated by Bouhadiba [10], a formula that is proposed by Ferguson [18] which does not actually corresponds rightly to the linguistic profile of Algeria; for many reasons, firstly; diglossia is becoming unstable as it has already been mentioned. Evidence from our real life is the following instances appearing in the speech of a teacher inside the class with her pupils:

/ftah 1 kta:b șafha talŁaৎ $\int /$

(Sentence 1 refers to "open your books on page thirteen"; this sentence is said in dialectal form i.e. in Algerian Arabic dialect)

Rightly, should be said in the following manner to equip with the $(\mathrm{H})$ function of Standard Arabic in the formal setting i.e., classroom;

/Iftah lkita:b safhat $\Theta a$ la $\Theta a$ Pa $\int$ ara/

(Here sentence 1 is rightly said in the Standard form i.e.; standard Arabic)

/ Sku:n li jaSraf 1 zawab?/

(Sentence number 3 stands for "who knows the answer?" it is uttered in Algerian Arabic dialect)

Again, the right utterance (-sentence 3) in Standard Arabic (H) is:

\section{/man ja?rif əl izaba/}

Secondly, the low rate of a bilingual production among the individual speakers. It is noticed that, particularly young are becoming more monolingual. In addition they show no high potentials in Standard Arabic production as well.

Thirdly, despite the fact of its standardization; Tamazight lacks its real status. It's teaching till now does not cover all Algerian schools, but a decision is made to be implemented in 2017 that its teaching must be generalized in all educational institutions of Algeria.

It is the following rectangular form that we propose, here; that may best explain and may bring clear image to the Algerian linguistic situation; which represents the relationships and functional roles of the language varieties in Algeria, considering in that two main phenomena: bilingualism and diglossia.
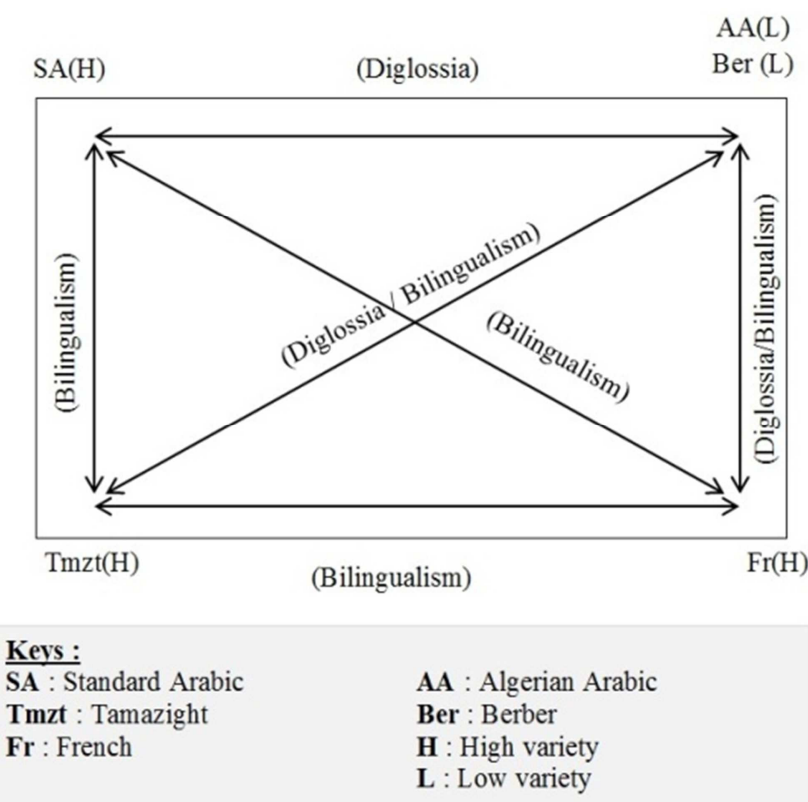

Figure 3. Development of the Algerian Linguistic Landscape.

The diagram represents our attempt to bring evidence to our observation to our actual Algerian sociolinguistic landscape. Thus, this diagram is constructed to reflect the actual landscape which consists of three major standard or official languages (SA, Tmzt, and Fr), in addition to two minor language varieties or low varieties Algerian Arabic and Berber with respect to its regional variation. And foreign languages, namely English language used in education and in some other formal situations.

So, from the previous diagram the following relationships can be distinguished, or one can demonstrate the linguistic relationships between the five language varieties as follow:

Table 1. Total Relationships between Five Language varieties.

\begin{tabular}{lll}
\hline 1 & Standard Arabic/ & Tamazight \\
2 & Standard Arabic/ & French \\
3 & Standard Arabic/ & Algerian Arabic \\
4 & Standard Arabic/ & Berber \\
5 & Tamazight / & Standard Arabic \\
6 & Tamazight / & French \\
7 & Tamazight / & Algerian Arabic \\
8 & Tamazight / & Berber \\
9 & French / & Standard Arabic \\
10 & French / & Tamazight \\
11 & French / & Algerian Arabic \\
12 & French / & Berber \\
13 & Algerian Arabic / & Standard Arabic \\
14 & Algerian Arabic / & Tamazight \\
15 & Algerian Arabic / & French \\
16 & Algerian Arabic / & Berber \\
17 & Berber/ & Standard Arabic \\
18 & Berber/ & Tamazight \\
19 & Berber/ & French \\
20 & Berber/ & Algerian Arabic \\
\hline
\end{tabular}

Therefore, a total number of 20 relationships between languages and language varieties are obtained. For purposes to avoid the same in order not to say repetitions we keep only 
the following assuming in that that they reflect the sought new situation which answer the question in hand. The relationships are:

Table 2. Representative Core Relationships between Five Language varieties

\begin{tabular}{lll}
\hline 1 & Standard Arabic/Tamazight & (Bilingualism) \\
2 & Standard Arabic /French & (Interlingual diglossia+ Bilingualism) \\
3 & $\begin{array}{l}\text { Standard Arabic /Algerian } \\
\text { Arabic }\end{array}$ & (Intralingual diglossia) \\
4 & Standard Arabic /Berber & (Interlingual diglossia+ Bilingualism) \\
5 & Tamazight /French & (Interlingual diglossia+ Bilingualism) \\
6 & Tamazight /Algerian Arabic & (Interlingual diglossia) \\
7 & Tamazight /Berber & (Intralingual diglossia) \\
8 & French /Algerian Arabic & (Interlingual diglossia+ Bilingualism) \\
9 & French /Berber & (Interlingual diglossia+ Bilingualism) \\
10 & Algerian Arabic /Berber & (Bilingualism) \\
\hline
\end{tabular}

Sociolinguistic realities give, however, a different picture. Algeria is eminently characterized by multilingualism and multiculturalism. Given the existence of three languages and two dialects in competition, Standard Arabic, Tamazight, French, Algerian Arabic, and Berber there results a combination of several types of diglossia and several types of bilingualism, according to the relationships in which these languages and language varieties stand to one another. Ten major types of relationships exist.

To make emphasis, here, the terms of diglossia and bilingualism are used according to Fishman's [19] definition of the term diglossia, i.e. to cover functionally differentiated language varieties of whatever kind. And, the use of the term bilingualism, following Wexler [40], we distinguish between intra-lingual diglossia where they are not related. Bilingualism is used here to mean the use of two or more languages in contrastive distribution.

As a matter of fact, our proposed diagram, entitled: Development of the Algerian Linguistic Landscape constitutes of ten main significant relationships, as mentioned above, which are tested in social interactions, what remains clumsy for the time being is the Tamazight/ Algerian Arabic relationship; it is quite evident that there exist an interlingual diglossia due to the non-genetically relationship between the two linguistic systems, nevertheless, whether or not there exist a bilingualism relationship between both language varieties in the Algerian context is far from being clear. As far as this relationship is concerned, no field work study was achieved through observation or any other procedure; because of some considerations - not of a linguistic type.

\section{A Socio- Politico/ Socio- Linguistic Background to Arabisationin Algeria}

Dealing with another concept Arabisation $^{36}$, but keeping the same sociolinguistic framework that will show that Algeria, like the other countries in North Africa, has long become an Arabic-speaking country, more precisely since the

\footnotetext{
${ }^{36}$ The information provided in this account are IBS JOS: An open access peer reviewed multidisciplinary journal.
}

arrival of the waves of Banu Hilaal in the $11^{\text {th }}$ century. These tribes came to the Maghreb for the sole purpose of spreading the religion of Islam.

In this respect, Cheyne [13] ${ }^{37}$ says: Although the Arabs find themselves politically divided, their language betrays a unity more basic than any single institution. What is also meant by Arabisation, in the case of the countries of the Maghreb, is in fact a re-introduction, i.e., a second process undertaken by the Algerian independent government.

Tracing the objectives of Arabisation, it was, thus, claimed by President $H$. Boumediene [11] that its aim is the Arabisation of French legislation by Arabising juridical texts, teaching, cinemas, and an ambitious aim was the Arabisation of scientific research, industrial management and administrations in the Petrochemical factories of Skikda and El-Hadjar. He added that the Arabic language would be the language of iron and steel if the Algerian petrochemical factories were Arabised.

Furthermore, the important objective that was aimed at was to remedy the effects of the so-called cultural colonization. K. Taleb Ibrahimi [37] points out that Arabisation is an essential procedure of the Cultural Revolution after the industrial one. However, despite the Arabisation of certain social domains, namely teaching and administration, the process appears to meet serious problems. This is not restricted only to the Algerian linguistic situation, but also to the other Maghreb countries. This is due to a paradoxical measure undertaken by the government's decision which advocates that Arabic has to be the language of instruction and teaching, but, in parallel, some other private schools are built in the capital-city and pupils pay for learning an instruction in French.

The other problem is the enormous impact that Algerian Arabic exerts upon the competences of most Algerians, consequently, no right and appropriate use of a pure Standard Arabic can be noticed in their discourse. In this respect, Bentahila [6] ${ }^{38}$ points to the fact that Arabic itself has been felt to cause problems for arabisation. One crucial factor is the diglossic relationship which exists between the two varieties of Arabic (op. cit), which are so different in structure and in function. It seems to be generally agreed that Standard Arabic is the most appropriate vehicle for Arabisation, for two main reasons: its links with the religious and cultural heritage, and its role as a unifying factor in the Arab world. Nevertheless, Arabisation as an objective and a process has encountered objections by many who believe that the Arabic language cannot serve modern societies efficiently and the present civilisation of the world, as it is mentioned above.

Another often-cited shortcoming is the fact that most Algerians strongly rejected the idea that Arabic language cannot serve all daily communication. A. Taleb Ibrahimi claims that $[36]^{39}$.

Among the families which worry about the future of their

\footnotetext{
${ }^{37}$ [13] Cheyne. 1969, p. 174- 75.

${ }^{38}$ [6] Bentahilla. 1987, p. 235.

${ }^{39}$ [36] Taleb Ibrahimi. 1973, 102-103.
} 
children, about the existence of job opportunities corresponding to the training they have received, which realize that today, it is French above all which ensures a livelihood... it turns out that those who hold degrees in Arabic encounter difficulties in getting jobs in certain administrations. ${ }^{40}$

All in all, the question of the Arabisation and the substitution of French by Arabic, particularly in formal language use remain debatable; it is becoming an important issue of serious political and linguistic researches.

\section{The Weight of Languages in the Actual Sociolinguistic Landscape}

Here, the prime concern is neither to give a concrete weight nor to establish an authentic scale for languages used in Algeria. It is rather a misleading question to deal with the status of languages in a whole society, their uses under the influence of the actual globalised world. We may venture to say that it is wrong to determine the linguistic situation in Algeria, this dictated, first, by both the linguistic diversity and the cultural one, too. Moving, therefore, from North to South and from West to East we recognize the large gap existing among the individual speakers what about the linguistic varieties they are using? They are variable. This is due to the impact of the regionalism above all. Therefore, a thorough examination of the linguistic situation in Algeria should take for granted the geographical situation which may add useful information about the social context, and history more importantly of the desired site to be investigated.

Preliminary findings to our daily observation are:

1) The existence of three $(\mathrm{H})$ varieties: Standard Arabic, Tamazight, and French which play a major role is confirmed in addition to the learning of foreign languages, nevertheless, Chinese has already established its existence, too. Anyone can read some road sings on which it is mentioned as fellow:

$1^{\text {st }} /$ Chinese

$2^{\text {nd }} /$ French

$3^{\text {rd }} /$ Standard Arabic

2) Under Bouteflika's presidency and the politicoeconomic relationships in the globalised world, Chinese were welcomed to contribute to construct in the making of modernized Algeria. But is it a short term or long term situation?

3) No active bilingualism is noticed in Algerian's linguistic productions. Bilingualism is becoming a characteristic feature to the individual speakers in the capital city, Berbero-phone regions and some other big cities like Oran.

\footnotetext{
${ }^{40}$ The original passage reads as follows (my translation):

Parmi les familles qui s'inquiètent de l'avenir de leurs enfants, de l'existence de débouchés correspondant à la formation qu'ils ont reçue, qui se rendent compte qu'actuellement c'est surtout le français qui assure un gagne-pain...il s'avère que les diplômés en Arabe éprouvent des difficultés à obtenir des emplois dans certaines administrations.
}

4) The linguistic situation is certainly becoming unstable. As it has already been said no active bilingualism led crucially to the monoligualism among young group. This may be explained from another side as a consequence of Arabisation policy of the teaching. Besides, the disruptive functional roles of $\mathrm{H} / \mathrm{L}$ varieties. Because, first, of the high rate of the illiteracy rate of old group and second, by the no mastery of either language by young group, this results in the use of the mother tongues or L varieties (i.e. Algerian Arabic and Berber) in even formal settings.

5) It is becoming evident that Arabisation as a policy and a procedure has failed in many respects to fulfill its objectives. This may be explained as a lack of thoughtful and authentic investigation, it was imposed by des hommes de politique and les hommes de politique se trompent.

6) Despite the fact that Le printemp Berber is reached and consolidated by Bouteflika, and Tamazight has shifted its dress to a national, then, to an official language it is still marginalized.

7) In front of the widespread view that Algeria is the second francophone country after France, nevertheless, quantitatively speaking the use of French language has reduced among Algerians. Paradoxically, what is noticed is the fact of using either loanwords which are rooted in their repertoires or code switching, except for the elite mass.

8) In this linguistic landscape, a linguistic insecurity is marked of either language, but a new tendency is appearing by the change of the characters of distinct signs from Arabic to French or English- in sophisticated places in the city centers mentioning things, such as Pizza Hot, Fast Food, Boutique Eve. Do these renovated signs call for an alarm? After language problems are we encountering another one which may be a problem of identity/ or even identities? And, again are the social classes in the making?

To put all in nutshell, the study of the sociolinguistic situation of Algeria as it constitutes our concern is somehow misleading. We should look to that society as composed of distinct parts each of which has peculiar socio-political, socio-cultural and socio-economic characteristics. All bring forth un tout ou tout se tient. We, therefore, make our force like all the other peoples by language or any other factor building identities.

Language is not only a means of communication but a determinant of the socio-political, socio-cultural, socioeconomic of people, and a symbol of identity, too. ${ }^{4 I}$

\section{Conclusion}

This paper is intended to provide a description of the actual Algerian linguistic landscape to examine particularly

\footnotetext{
${ }^{41}$ My conclusion drawn in a formal essay in ALTALA Lab- university of Tlemcen in 2011.
} 
the interaction of Algerian Arabic with the other language varieties. Interestingly enough, one may stress the fact that upon the evolutionary character of languages and their dynamics and the influences that one language variety exerts upon another. It is related, in a way or another to the dynamics of the social and cultural aspects. The interaction of these languages leads us to draw the actual language phenomena as they happen in the Algerian linguistic context. Therefore, in spite of the Arabisation process and policy, French is still present. The authentic status that that language occupies in society will surely influence the other existing languages primarily the dialects with a heavy admixture of borrowings as well as code switching, in contrast to English which is restricted to educational or specific purposes only.

Besides, the individual's language choice is of a paramount importance to a decision about what the prestigious and appropriate language is. Therefore, it is in their language use, that the individuals can socially identify themselves. In this respect, Grandguillaume [22] ${ }^{42}$ notes, language is not only a means of communicating, but it is also the place where a man may determine his identity ${ }^{43}$.

Eventually, the Algerian linguistic scenery seems to reflect an ambiguous setting. It is observed that diglossia in Algeria is becoming unstable, first because of the increasing rate of the illiteracy, and secondly because of the disruptive functions of the $\mathrm{H} / \mathrm{L}$ varieties, in addition to the production of speech that is full of code-switching. This consists of a mixture and co-existing of different linguistic elements from distinct linguistic codes.

In summary, the linguistic situation is extremely complex which would rather be considered as richness and a sign of vitality.

\section{References}

[1] Abdulaziz, M. H. (1986.) Factors in the development of modern Arabic usage. In: International Journal of the Sociology of Language, 62, 11-24.

[2] Ait Larbi, A. (2006.) Bouteflika ferme des école francophones http://www.lefigaro.fr/internationale/20060228_bouteflika_fer me_des_ecole_francophone.htm.

[3] Appel, R. and Muysken, P. (2005.) Language Contact and Bilingualism. Amsterdam University Press.

[4] Basset, A.(1952.) ARABIYYA. In: Encyclopedia of Islam, 561601.

[5] Benrabah, M. (2007.) The Language Planning Situation in Algeria. In: Kaplan, R. and Richard Baldauf, R. (eds.) Language Planning and Policy in Africa, vol. II. Clevedon: Multilingual Matters, 25-147.

[6] Bentahila, A. Language Attitudes as an obstacle to Arabisation. In: Descout, R. (1987.) (Ed.) Applied Arabic

\footnotetext{
42 [22] Grandguillaume. 1983, p. 23.

The original passage reads as follow:

${ }^{43}$ La langue n'est pas seulement un outil pour communiquer, elle est aussi le lieu où l'homme repère son identité. (my own translation)
}

Linguistics and Signal and Information Processing. Hemisphere Publishing Corporation: USA.

[7] Bishai, W. B. (1966.) Modern inter-Arabic. In: Journal of the American Oriental Society 86, 319-23.

[8] Bloomfield, L. (1933.) Language. Henry Holt: New York.

[9] Bouamrane, A. (1986.) Aspects of the Sociolinguistic Situation in Algeria. Unpublished Ph. D Thesis. University of Aberdeen: United Kingdom.

[10] Bouhadiba, F. A. N. (1998.) Continuum linguistique ou alternance de codes? Essais D'analyse dynamique des faits et états des lieux. In: Cahier de Linguistique et Didactique, 1, 111. ILE: University of Oran.

[11] Boumédienne, H. (1975.) La stratégie de Boumédienne. Collection textes Politiques. In: Bernard, P. (ed.) (1978). La bibliothèque Arabe, Sindbad: Paris.

[12] Caubet, D. (1999) Questionnaire propose par Dominique Caubet d'apres les questionnaires de M. Cohen, D. Cohen et A. Roth et les travaux de W. Marçais, S. Levy. In: Journée d'étude en Dialectologie du Maghreb.

[13] Cheyne, A. G. (1969.) The Arabic Language. Minneapolis: University of Minnesota Press.

[14] Dendane, Z. (1994.) Sociolinguistic variation in an Arabic Speech Community: Tlemcen. In: Cahiers de Didactique et de Linguistique Contrastive $I V, 1-2: 62-77$. ILE: University of Oran.

[15] Dendane, Z. (2007.) Sociolinguistic variation and Attitudes towards Language Behaviour in an Algerian Context: The Case of Tlemcen Arabic. Unpublished Ph. D. thesis. ILE: University of Oran.

[16] Ferguson, C. A. (1959.) The Arabic Koiné. Language, Vol. 35, $\mathrm{N}^{\circ} 4$, pp. 616-630.

[17] Ferguson, C. A. (1959a.) Diglossia. In: Word 15, 325-40.

[18] Ferguson, C. A. (1966.) National Sociolinguistic Profile Formulas. In: Bouhadiba, FAN. (1998.).

[19] Fishman, J. (1972.) The Sociology of Language. In Giglioli, P. P. (ed.) (1972.), 45-58.

[20] Fishman, J. (1971.) In: Hudson, R. A. (1996) (2nd Ed.).

[21] Grandguillaume (2004.), in: Morsly, D. (1990.) En Arabe Classique le Journal Ttélévisé? In: Maghreb Linguistics. Okad: Rabat, 447, 163-74.

[22] Grandguillaume, G. (1983.) Islam d'hier et d'aujourd'hui: arabisation et politique linguistique au Maghreb. In: Edition G-P Maisonneuve et Larousse. Paris.

[23] Hudson, R. A. (1996.) (2nd Ed.) Sociolinguistics. CUP: Cambridge.

[24] Kaye, A. (1994.) Formal vs. Informal in Arabic: diglossia, triglossia, tetraglossia, Etc..., multiglossia- polyglossia viewed as a continuum. In: Journal of Arabic linguistics, 27, 47-66.

[25] Macnamara, J. (1969.) How can we measure the extent of a person's bilingual proficiency? In: Kelly (ed.) (1969.) pp. 7997. 
[26] Marçais, W. (1930.) La Diglossie Arabe. In: L’Enseignement public 12, 401-09.

[27] McLaughlin, L. J. (1972.) Toward a Definition of Modern Standard Arabic. In: Archivum Linguisticum, vol III, 57-74.

[28] Moatassime, A. (1979.) Langage et Politique au Maghreb. Contribution à l'Elaboration d'une Politique Linguistique dans les Systèmes Pédagogiques Maghrébins à la Lueur d'une Etude sur le Langage à l'Ecole dans ses Rapports avec l'Evolution Politique au Maroc de 1957 à 1977. Ph. D thesis. University of Paris I.

[29] Morsly, D. (1984.) La Langue Etrangère: Réflexion sur le Statut de la Langue Française en Algérie. In: Le Français dans le Monde, 189, 22-26.

[30] Morsly, D. (1988.) Le Français dans la Réalité Algérienne. Ph. $\mathrm{D}$ thesis. University of Paris V.

[31] Morsly, D. (1990.) En Arabe Classique le Journal Ttélévisé? In: Maghreb Linguistics. Okad: Rabat, 447, 163-74.

[32] Morsly, D. (1997.) Tamazight Langue Nationale. In: Laroussi, F. (ed.) Plurilinguisme et Identités au Maghreb, Rouen, PUR, 33-43.

[33] Parkinson, D. B. (1991.) Searching for Modern fuş九a: real-life formal Arabic. In: AlarbiJa, 24, 31-64.
[34] Sayahi, L. (2014.) Diglossia and Language Contact: Language Variation and Change in North Africa. Cambridge: Cambridge University Press.

[35] Shiffman, H. (1997.) Diglossia as a Sociolinguistic situation. In The Handbook of Sociolinguistics. Coulmas, F. (ed.) Oxford: Blackwell, 205-16.

[36] Taleb Ibrahimi, A. (1973.) De la décolonisation à la révolution culturelle. Société Nationale d'Edition et de Diffusion: Alger.

[37] Taleb Ibrahimi, K. (1997.) Les Algériens et leur (s) langue (s): élément pour une approche sociolinguistique de la société algérienne. Les Editions El- Hikma: Alger.

[38] Trudgill, P. (1974.) Sociolinguistics: An Introduction. Harmondsworth: Penguin.

[39] Weinreich, U. (1953.) Languages in Contact: Findings and Problems. The Hague.

[40] Wexler, P. (1971.) Diglossia, Language Standardisation and Purism. Parameters for a Typology of Literary Languages. Lingua 27: 330-419.

[41] Youssi, A. (1983.) La Triglossie dans la Typologie Linguistique. In: La Linguistique, vol II, 19, 71-83. 